\title{
Narrative-Verse: On Transmedia, Narrative And Digital Media Audiences
}

\author{
Herlander Elias \& Flávio Almeida \\ LabCom.IFP / UNIDCOM, LabCom.IFP \\ E-mail: herlanderelias248@gmail.com/ email.flavioalmeida@gmail.com
}

\begin{abstract}
Current trends point at narrative as a way of better doing storytelling, and as a medium in itself to accomplish brand awareness. Works of fiction are empowered by new narratives as they intersect one another through the release of new narrative films, novels, games and TV shows. In the background of today's post-modern reaction to narratives lies the fact of post-modernity declaring the fall of the grand narratives. With no massive narrative to tie ourselves together, we stand vulnerable to narratives provided by films, TV shows, gaming and new novels targeting

ena, we will analyse the Ridley Scott's Alien franchise as a case of study to search for how a story can evolve throughout the years and cross the boundaries of cinema to be present in multiple media. The subject of consistency, gender studies, technology, story world, transmedia storytelling and decentralised information will be the subjects of our analysis. One of the utmost important features we can draw as a conclusion is that the mainstream viewer, or the casual gamer, is no more the rule. These days we are all seekers and searchers, not just passive viewers.
\end{abstract} mass adoption. To better understand this phenom-

Keywords: transmedia; narratology; Ridley Scott; Alien.

\section{Our Context}

CURRENT trends point at transmedia as a way of better doing storytelling and as a medium in itself to accomplish brand awareness. Works of fiction are empowered by new narratives as they intersect one another through the release of new narrative films, novels, games and TV shows. In the background of today's post-modern reaction to narratives lies the fact of post-modernity declaring the fall of the grand narratives. With no massive narrative to tie ourselves together, we stand vulnerable to narratives provided by films, TV shows, gaming and new novels targeting mass adoption. For psychologist Sherry Turkle “(...) there is no simple narrative of 'digital natives' at ease in the world they grew up in. On the contrary. The story of conversation today is a story of conflict on a landscape of clear expectations" $(2015,31)$. Conversation is exactly what happens

Data de submissão: 2017-11-16. Data de aprovação: 2018-04-22.

A Revista Estudos em Comunicação é financiada por Fundos FEDER através do Programa Operacional Factores de Competitividade - COMPETE e por Fundos Nacionais através da FCT - Fundação para a Ciência e a Tecnologia no âmbito do projeto Comunicação, Filosofia e Humanidades (LabCom.IFP) UID/CCI/00661/2013.
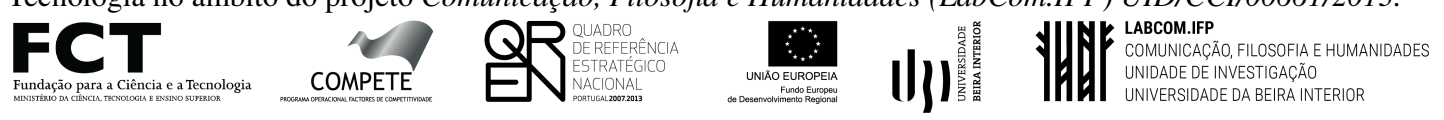
to the brands of fiction and the narrative worlds designed by creative writing, and at the same time conversation is the new dialogue with the new narratives. Engagement means we reach out to narratives and stay aware of the unfolding new worlds of narrative that media release. Should we refer to conversations in themselves, and Turkle's arguments, again, prove to be quite useful for she says that "Conversations help students build narratives (...) that will allow them to learn and remember in a way that has meaning for them" $(2015,8)$. Put another way, dialogue allows people establishing narratives, so the best narratives come from dialogue; the imagination of people bridging the imagination of the creators of narrative universes, what we hereby call of "narrative-verses". This narrative-verses are designed to grow up in size by feeding the audience with clues and puzzles, but also by feeding themselves on the public's imagination and interaction.

We are told by Luc \& Vervaeck that in a postmodern description of narrative space "multiplicity" and "metamorphosis" are key-features. They quote Francese, for whom this postmodern space works out as a form of "flux" and "multiperspectivism". Also, author Punday connects both "spatial multiplicity" to "alterity" (apud Luc \& Vervaeck, 2005, 113). In this context we may assert that the new narrative-verses perform as spaces of flow, where narratives interconnect by referring to a single semiotic ground, and displaying bridges to many mediums in which the narrative-verse is connected to. As the background is the same semiotic universe, but the bridges outnumber the universe in inputs and outputs, we witness many perspectives and a sort of multiplicity in space, as each and every person interacts with the narrative-verse differently by relying on the media that previously has chosen what we have to consume and understand.

In the pursuit of clues, watching movies frame by frame, searching online for a better understanding, we come across with many challenges, and it is also true we become searchers in a culture of multiple views based on a single macro-narrative. We choose to comprehend better these universes of narrative by assembling parts and decoding the cyphers. In this sense we almost build a macro-theory about it, and each person has its own para-theory on the issues of the narrative-verse. Hyper-theory, on its own, does not explain the big picture. One needs to fit knowledge from several sources in the theoretical framework in order to have the full map, almost entirely, of narrative-verses that seem always unfinished.

One of the features that seems to prepare ourselves to decode massive narratives of fiction is that we have inside ourselves what Freeman calls "a narrative unconscious", which means that each culture has an analogue of our personal unconscious, and it stands related to historical events (apud Jonathan D. Raskin in Bamberg \& Andrews, 2004, 318). What this means is that we behave towards narrative worlds of fiction in the same way we find ourselves before historical facts. We tend to find meaning and understanding of the whole chronological big picture. We tie loose ends in order to assemble a framework of meaning so we can see ourselves to fit better in the narrative of the world we live in. As for the narrative-verses the same thing happen, except that media release new narrative worlds, feed us with clues and links so we can assemble the real meaning by purchasing more and more items. The consumer who purchases more episodes, movies, books and games, will have a clearer insight on the wholeness of the story.

Molly Andrews believes that ultimately the power of master narratives derives from their "internalization" (apud Bamberg \& Andrews, 2004, 1), which means that we somehow absorb and choose to assimilate in our "narrative unconscious" the parts of the larger narrative-verse we enjoy 
most to decode. Ultimately, it is all about how "participants" fit in a world in which there is a process of "identification" between people and the world of fiction (Idem, Ibidem).

Narrative is not the single discourse genre nor it is the only way of rethoric that authors choose to communicate with their audiences. Nevertheless, there is a certain "narrative format" that drives us towards narrative, as especially to narrative-verses. Here we have more options and the stories unfold in the pace we choose to play with. There are many speech genres and ways to do storytelling but narrative provides us with a gameplay that is ideal to feed our "narrative unconscious". A simple example lies in how we deal with narrative-verses from the scale point of view. Narratives are being reduced to numbers, something similar to wearing wearable computing. Our media track our trajectory and a narrative unfolds based on our performance. The same thing happens with narrative worlds that are massive. But we remain the performers of a situation, we are the searchers and the readers, the decoders and the viewers, the players and the consumers of stories that require the purchasing of many parts before we have a grasp of the full meaning. These worlds are designed by design-fiction, a new procedure to encompass audiences that participate and creators that sort of create a world fit to play with. "You can construct narratives around our numbers", says Turkle $(2015,91)$, and she is right. To have a clear picture of what is going on in a narrative-verse one must collect many episodes, sagas, novels published, games released and movies premiered. We become collectors of information that has an hidden meaning. Our goal is to achieve the best understanding out of it.

For Nicholas Taleb, the issue is best understood if we keep in mind that in Greek mythology there were two brothers that somehow highlight the poles of our discussion. It is said that

"In Greek legend, there were two Titan brothers, Prometheus and Epimetheus. Prometheus means "fore-thinker" while Epimetheus means "after-thinker," equivalent to someone who falls for the retrospective distortion of fitting theories to past events in an ex post narrative manner. Prometheus gave us fire and represents the progress of civilization, while Epimetheus represents backward thinking, staleness, and lack of intelligence" (2012, Book IV, Chapter 14).

As for our context of discussion, we could say that the design-fiction process bears the principle of surrounding us with clues and traces of a massive narrative. This is our promethean side we look into the future of understanding, we accumulate data and explanations arise. On the other hand, our epimethean side tells us that there is too much information so we should take a look into the past, just in case. In sum, to best decode the whole structure of massive narrative-verses one should look forward (promethean aspect) and also look backward (the epimethean aspect).

\section{Narratology And Literature-Space}

For Kevin Kelly, “(...) there is a power in the long form. A self-contained story, unified narrative, and closed argument has a strong attraction for us" (2016, Loc 1497-5810). We are driven by this concept of the self-contained story and the unified narrative, we look for it, we see power in such long form where the so-called narrative format and the "narrative unconscious" get more consistent. Today, we consume narratives on screens. Wherever we stare at, there are 
screens with stories, piece by piece there is meaning rising from the scattered parts. A whole universe of meaning makes sense as long as we keep consuming and interacting with screens, books, shows, games and movies. In each screen there is a medium, whether it is a smartphone, a tablet, a phablet, a computer or smart TV. These are the media in which we have connection to the narrative universes. "Those stories will play across screens. Everywhere we look, we see screens" (Idem, Ibidem,, Loc 1502-5810).

When we deal with the narrative-verses, we behave like players, we accumulate points, we move from one level of understanding to another, we go from amateurs to professionals. We become connoisseurs. We are surrounded by new movies, games, apps and books, episodes of fiction that connect to something bigger. Our role here is to become "connectors" of something greater. But Turkle underlines that "Apps [specifically] can give you a number; only people can provide a narrative. Technology can expose a mechanism; people have to find meaning" (2015, $81)$.

In what concerns narratology authors Susana Onega and José Angel García Landa say "A narrative is the semiotic representation of a series of events meaningfully connected in a temporal and causal way" (in Luc \& Vervaeck, 2005, 13); it is exactly this semiotic representation of a series of events that we try to map out in order to fully understand a narrative-verse. We are working out the semiotics in order to feel less overwhelmed by narratology. Simply speaking, narratology is the theory of the narrative text, and a narrative is a sequence of events. The whole problem lies in how we can define an "event" (Idem, Ibidem, 2). In narrative-verses, events are the releases of fiction and the contents inside them, being both the media and the storytelling. Also, narratives tend to be held hostage of certain platforms. Take, for instance, books as one platform, gaming consoles as another, movies that we stream as another or TV, too.

For Taleb, there is a certain "Narrative Fallacy: Our need to fit a story, or pattern, to a series of connected or disconnected facts. The statistical application is data mining" (2012, Book VII, Conclusion). Due to the size of the narrative-verses, it becomes a fact that we sort of data-mine everything in order to have a full grasp of the total meaning. The fallacy has to do with the real achievement of understanding, meaning that no matter how much media we may consume, we might never truly understand a narrative-verse, as more perspectives about a certain space of narrative keep rising. On the other hand, the more media we consume the more we keep entitled to become experts in such matters. Besides being searchers, and information-gatherers, we become foremostly consumers. It is said by Kevin Kelly that this conceptual state of imagination one might call it "literature space" (2016, Loc 1322-5810).

We must keep in mind that in this "literature space" the narrative format is king, and there is also the issue of how narratives, so big as the ones in the narrative-verse, are unfinished - an endless narrative. Kelly believes that narratives traditionally made on paper are no more suited for updating and searching (Idem, Ibidem, Loc 1364-5810). However, what is happening is that in the absence of a static grand narrative, we find ourselves dealing with a versatile, beta-narrative, a format of narrative designed by design-fiction to allow narrative-verses to grow exponentially. It is all about a sequence of events, stories that provide more bridges than endings; they provide sequels and prequels and gaming situations; they introduce us to puzzles and enigmas. So, as the literature-space gets bigger, so does our comprehension of a certain matter, of a certain narrative- 
verse, its ambient world and the characters living on it. What is happening to the literature-space is that the narrative-verse amplifies it with images that are textes in their own. So ultimately everything becomes a larger text, something we may only understand if we resort to more "texts".

French philosopher Gilles Deleuze said that "For me, a text is nothing but a cog in a larger extra-textual practice. It's not about using deconstruction, or any other textual practice, to do textual commentary; it's about seeing what one can do with an extra-textual practice that extends the text. You ask me whether I believe in nomads as an answer" (Deleuze, 2004, 260). And because we rely on more textes, we become "nomads" in Deleuze's sense, meaning we could have journeys without leaving one place, meaning we could resort to extra-textual material to travel away from the narrative-verse only to find out that we need to go back in order to understand it even better. Literature-space here is an extended text as Deleuze suggests.

In our perspective, movies and games are intertwined. Narratives requiring attention or participation are orbiting these two media. Movies, for instance, have a universe of their own. Author Arlindo Machado says that cinema has learned to tame the pulses with a sort of cultural framework by which it sublimes, corrects, "civilizes" the chaotic narratives forged on the unconscious (1997, 71). Same is to say we have both a narrative and a cinematic unconscious. And having said this, we also should keep in mind that the beta state of narratives provide us more strings to connect to. Lose images invoke our attention, while interactive images summon our participation. The remaining grid comes from text. We are forced to find extra-textual material in order to understand what is going on a movie, TV show, game or book. Machado says that cinema is getting closer and closer from the literary ideal of a narrative controlled in its most minimal details (Idem, Ibidem, 186). But our main concern should be what Luc \& Vervaeck call of as "Cyber-narratology":

"A marginal case, which we will only touch upon, is cybernarratology. This approach is mainly concerned with so-called "hypertexts"; that is, all kinds of digital texts that collect data in a network in which a (potentially infinite) number of nodes are connected to each other in a (potentially infinite) number of ways. Apart from language, graphics, sound, and video material can be part of the hypertext. Well-known examples are video and computer games, multimedia stories, interactive texts, and websites" $(2005,106)$.

Today, everything is about connectivity, and thus about cyber-narratology, how events of a narrative seem scattered across the fragmented landscape of media. Our role is to connect the dots. We are the builders of the new literary-space, the searchers and consumers, the readers, viewers and gamers that follow the hyper-links in this digital culture. We are looking for meaning. The object is still a text, even in images, these images are a meta-code for texts. "In other words, certain units can be mixed, giving a play of possibilities in the narrative economy" (Barthes, 1993, 97).

\section{Rhizomes And Narrativizing}

The narratives we are consuming are more than literary, they are un-centered structures, labyrinths, rhizomes that propagate like horizontal meshes, hyperlinked viruses, connections outnumbering the elements they closely connect. These narratives are also a sophisticated format of 
text designed by design-fiction as a way to lead and "mesmerize" consumers with pre-established bridges. Let's not forget the term "narrativizing - as the activity of engaging in narratives" (Bamberg in Bamberg \& Andrews, 2004, 359). Although there is a narrative economy that proves to be quite profitable, we shouldn't forget that by engaging with these new economies of text we become more imprisoned by their own nexus. We are locked-in consumers. But then again, even cultures must possess narratives (Postman, 1994, 150).

We engage with narratives, narrativizing with extended texts. There is a process from world to word, and then another one from word to world. For science fiction writer Bruce Sterling, the narrative universes are part of design-fiction $\mathrm{H}$ they do not come from narrative, story and plot. "He described design-fiction as 'not a kind of fiction [but] a kind of design. It tells worlds rather than stories"" (Raven \& Elahi, 2015, 53). In this sense, what we have inherited is design-fictionbased-worlds, worlds of narrative that surpass stories of their own. It is all a by-product of text. Frissen et al say that "The kinds of narratives we come across (...) in popular culture often have a different form; they are, for example, multimedial, interactive, connected, and open-ended (in Frissen et al, 2015, 34). Their media have outperformed along with text the simple plot. We have to acknowledge that the media we use are all about cyberspace, the place that Gibson describes as a "narrative engine" in which stories unfold, where characters are surrounded by technological gear (Gibson in Neale, 2000). In Bukatman's point of view, "The subject is deconstructed through the interrelated synaesthetic operations of technology, narrative, and language" $(1993,180)$, and this very subject is the consumer who is buying more narratives than ever (Gibson, 2010, 21). Lunenfeld, for instance believes narrative surrounds us because it became the new ground (2011, $58)$.

In the transmedia context, Daniela Sasaki assures that every time we access to a narrative world, we find new entry-points, and we can access to the "big narrative scheme" $(2012,20)$ too. Also, for Max Giovagnoli there is "narrative contract" that hyperlinks both authors and audiences $(2011,24)$. Everybody is looking for the master-narrative, the narrative behind it al. What we are looking for is a new "Narrative device" (Newell in JJ Abrams, 2013, 02m17s). What connects us $\mathrm{H}$ the narrative engine Gibson spoke about. We want to access to the connector events. “(...) When growing amounts of information are distributed at growing speed, it becomes increasingly difficult to create narratives, orders, developmental sequences. The fragments threaten to become hegemonic" (Eriksen apud Bauman, 2011, 41). And because they are hegemonic in their chaotic form, they fuel the "transmedial worlds" (Scolari, 2009, 588).

The semiotic systems that comprehend the current enhanced storytelling mean that representations in cross-platform narratives perform has a sort of viral, rhizomatic stories, that keep expanding no matter what. The audiences find the new narratives as narrative-engines that drive their curiosity. As for now, a story is no longer just a story anymore. Scolari notices that:

"The story that the comics tell is not the same as that is told on television or in cinema; the different media and languages participate and contribute to the construction of the transmedia narrative world. This textual dispersion is one of the most important sources of complexity in contemporary popular culture" $(2009,587)$. 
What we have here is a contamination of genres, since the story, as Scolari puts it, is not the same regardless of the media type, dispersion is what enforces the audiences to find meaning across a landscape of scattered items. Jay David Bolter also believes that in its simple form, interactive fiction demands only the two items we have identified in electronic writing: episodes (topics) and decisions (links) between episodes (1991, 122). From the audience's point of view everything becomes a question of managing links and connections, finding meaning in-between parts. The public is narrativizing contents, engaging them. What is left is what Hoepker calls "narrative snapshots" $(2011,45)$, frames from a larger film, pages from a larger book, levels from a larger game. This is why Douglas Rushkoff speaks of the "chaos of a postnarrative world" (2013, Chapter 1, 63-64-564, para.62). As the grand narratives worked out as a historical vest, and they have failed us to avoid holocaust, what is left is that the audience is prey to the predatory space of new narrative-verses provided by the media. New narratives are filling the gap. Transmedia happens to be what unfolds across multiple media platforms (Jenkins, 2006, 95). And somehow we are starting, amidst this fragmented landscape, to look after a "metanarrative" (Hoepker, 2011, 112). There has to be something bigger connecting all the dots.

One thing is sure, "Transnational multimedia conglomerates" (Kawamoto, 2003, ix) are allowing us to collect the many media contents to find meaning across several platforms. In the very core of this new image-text that audiences build along with the media there is meaning rising from the fragments. From the user's point of view, he or she is the key-holder; the user is the effective builder of the narratives in the way that he updates the likely associations in the right sequences. "More and more drama 'texts' are becoming multi-platform experiences, offering the viewer a variety of forms of engagement within the same coherent narrative world" (Evans, 2011, 173). In case there is some inconsistency in the narrative world, the users drop the engagement, but if the result is positive they will continue to push on in order to feel more psychologically immersed.

Jeffrey Sconce [2004] speaks of "world building" as the thing that has allowed for a wholly new mode of narration and that suggests new forms of audience engagement" (apud Evans, 2011, 10). Undoubtedly, the narrative-engines enabled with high-quality contents are driving the audiences. World building is what the audiences are a part of, as they are co-protagonists in the narrative-verses, they notice the attempt of producers in combining both "text" and "context" (Evans, 2011, 6). For Scolari, the issue is relation to ambition: "Now the objectives are much more ambitious; they aim to create a symbolic universe endowed with meaning (...) (in 2009, 599). And this symbolic universe endowed with meaning is simply addicting. We learn from Barthes that, at his time:

"The narratives of the world are numberless. Narrative is first and foremost a prodigious variety of genres, themselves distributed amongst different substances - as though any material were fit to receive man's stories. Able to be carried by articulated language, spoken or written, fixed or moving images, gestures, and the ordered mixture of all these substances; narrative is present in myth, legend, fable, tale, novella, epic, history, tragedy, drama, comedy, mime, painting (think of Carpaccio's Saint Ursula), stained glass windows, cinema, comics, news item, conversation" (1993, 79). 
As for now, yes! The narratives are countless, and as Barthes puts it, they are present in a variety of articulated languages and media forms, they are present in many story styles, but the substance, the narrative-engine is what the media producers are getting right in order to get our attention. The rhizomatic form of narrative keeps pushing boundaries and enabling ourselves to be partners in this venture of world building.

\section{Case Study: The Ridley Verse}

Considering the diversity of characters and the correlation between them, the Marvel's narrative universe is the world biggest narrative with dozens of movies, comic books, video games and television series. The Matrix, although has three feature movies only, could be noted as a complex attempt in the use of transmedia storytelling counting with web-based content, comics, videogames and a series of short animations called Animatrix. Nevertheless, considering the life span, the Alien franchise is an interesting case of study. The first movie was released in 1979. Since the success of that first movie, numerous videogames versions for multiple plataforms, spin off movies (Alien Versus Predator) and comic books were released. Even Ridley Scott's Blade Runner is considered to share the Alien's world narrative. Since the first release, through the transmedia releases, spin offs and the last movie, Alien: Covenant, this world narrative has been active for nearly four decades.

In such long period, the issue of consistency comes up. The visual issue is one of the most difficult aspects to deal with. The technology in cinema has evolved a lot since the analogical era of 1970's to the digital standard of today's cinema. Not only the technology involved in the movie making but the technology of everyday life. The prediction of the future in Sci-Fi movies regarding equipments, outfits and technology is frequent. In the end of 1970's the computers are still very expensive machines that were far from being popular and still not able of powerful capabilities. This aspect is very interesting to be analysed in Alien and its prequels Prometheus and Alien: Covenant.

The human technology, although advanced, is still imperfect. To make mistakes is part of the human nature. Thus, beings susceptible to error create machines which are also susceptible to error (Hobo \& Elias, 2017, p. 176). These minor errors are presented in glitches on the monitors. As degradation artifacts of tapes on the analogical screens in Alien or as digital glitches in Alien: Covenant, the consistency of technological failure is an aesthetic guide throughout the narrative world of Alien. Due to the time span of the the cinematic universe of Alien, it is difficult to maintain the technology's visual coherence along the movies. Both of them are prequels in 1979's. Alien: Prometheus was released in 2012 and Alien: Covenant in 2017.

Before Alien, the aesthetic style of sci-fi genre counted on films like 2001: A Space Odyssey, Star Trek, Star Wars among others. Actually, in an interview for WIRED (Locke, 2017) Ridley Scott said he was inspired by Stanley Kubrick's HAL 9000 character. The computer was in charge of the spaceship activities and maintenance in 2001: Space Oddissey and at certain point, it turned against the human crew. Like HAL 9000, the androids David and Ash represented a threat to the crew. The visual standard in these state of the art sci-fi movies from the 1970's usually is the white aseptic environment with high technological and minimalistic equipments. Spaceship 
Nostromo, depicted in Alien, has the heavy duty of towing a vehicle with a standard technology for the year $2122 \mathrm{AD}$. There is a darker, more entropic environment where the crew works and a lighter minimalistic one where the higher technological machinery stands. The sleep pods' room in Alien, the medical room in Prometheus and the Peter Weyland's room in Alien: Covenant share the same white, streamlined and minimalistic characteristics. All these characteristics opposes to the biomechanic aesthetic world of the aliens and the engineers created by Hans Ruedi Giger and very well depicted in Alien: Prometheus and Alien: Covenant. Actually, the biomechanic aesthetic originally idealized by H. R. Giger was always followed by other directors besides Ridley Scott, namely James Cameron in Aliens (1986), David Fincher in Alien 3 (1992) and Jean-Pierre Jeunet in Alien Resurrection (1997).

The storyworld of Alien franchising although complex has a continuous thread based also on the protagonists. The alien is, for sure, the core of this storyworld, but the androids and the female figure as leading role is very present in most of movies and video games. Ellen Ripley, Elizabeth Shawn and Daniels are the three female protagonists of the Alien cinematic world. In video games, Ellen Ripley has appeared in numerous video games adaptations and Amanda Ripley (Ellen's daughter) from Alien: Isolation (2014) are the most known characters. Aliens: Colonial Marines (2013) story takes place after the Aliens (ibid.) events showing a facehugger attached to Ellen Ripley's face. This event helps to explain the origin of the xenomorph in Alien 3 movie. Both Alien: Isolation and Alien: Colonial Marines are good examples of the so called new entrypoints where they can be accessed by the big narrative scheme regarding the transmedia context (as we cited earlier in this paper). The spin off movie Alien Vs. Predator (2004) has Alexa Woods as female protagonist. In a context dominated by muscular male heroes, specially during the $20^{\text {th }}$ century, the Alien storyworld is a breath of fresh air.

There are different strategies to work with stories to be broadcasted in transmedia. Dowd (2013) cites three of them: adaptation, extension and expansion. Adaptation will retell the story according to the new media requirements. The Alien franchise has all of them. The first videogame was released to Atari in 1982 and due to the console technical limitations the story is almost inexistent and the gameplay was very close to Pac-Man where the spirits of the ghosts were replaced by aliens and Pac-Man was replaced by Ripley.

The extension approach consists, still according to Dowd, of creating new narratives with the pre-existent material without introducing new story elements. In other words, there is no parallel events that relates to the main story. Alien 3 for SNES and Mega Drive are good examples of such strategy. Finally, Alien : Colonial Marines are good examples of the so called new entry-points where they can be accessed by the big narrative scheme regarding the transmedia context (as we cited earlier in this paper). In what concerns the expansion approach, as other transmedia storytelling strategy, it aims to broaden the original story by creating new stories that are related to the original one expanding the storyworld. As Dowd (ibid.) says "We are no longer tied to the specifics of the original story as long as we follow (or at least do not contradict) the established rules of the previous versions of the intellectual property." Aliens (1986), Alien 3 (1992), Prometheus (2012), Alien: Colonial Marines (2013) and Alien: Isolation (2014) are good examples of the expansion strategy. 
Alien as narrative has been engaging the audiences for decades using multiple media to present its content evolving narrative world. As an anonymous Hollywood scriptwriter once said:

"When I first started, you would pitch a story because without a good story, you didn't really have a film. Later, once sequels started to take off, you pitched a character because a good character could support multiple stories. And now, you pitch a world because a world can support multiple characters and multiple stories across multiple media" (Jenkins, 2006, 136).

The first Alien script was created to be a single movie. In the 1970's trilogies or narrative worlds were not the standard in film production. Alien has all the three elements cited here: a good plot, a good character (both Ellen Ripley and the alien itself), and now a good story world to be consistent across multiple media along the years.

The marketing approach to Prometheus and Alien: Covenant is a good example of transmedia use. With a solid story world, Ridley Scott released three short movies to advertise Prometheus. One of them shows Peter Weyland being a keynote speaker at TED Talk in year 2023. He talks about the future of human kind and introduces the new era of androids that is about to come. Other video is a kind of promotional one called Meet David video about David, the Weyland's most advanced product and the world's first android similar to a human. There is a viral video message about Elizabeth Shaw's memories addressed to Weyland's company. The last piece of marketing is the Project Prometheus website (Prometheus, n.d.) with a myriad of informations that help to extent the movie. For Alien: Covenant, the film producers joined forces with AMD to create the Meet Walter website (Meet Walter, n.d.). In this video, they show Walter's inception. It is possible to see they insert an AMD chip on Walter. This is an advertisement both for the Alien: Covenant film and the AMD. They used the story world and the hype of this new movie to tell the audience a story that is not in the movie and at the same time mixes fantasy (Alien story world) with reality (AMD is an actual computer company).

Narrative worlds and transmedia storytelling like these are aimed primarily to the seekers who are people who want to interact with the content. They, as Tom Dowd explains (2013), prefer to discover the content seeking in multiple platforms and deepen the immersion in the story world. So, the consistency of stories and the extra informations that help to expand the movie's story are important to maintain the interest of the seekers. These decentralized information should be interesting enough to keep them searching, but at the same time it cannot be crucial for the film plot itself because people who are interested in it must expect the unexpectable. On the other hand, other kind of seekers would not understand everything in that particular film plot due to the lack of information. So, balance is needed when media deals with narrative worlds and transmedia storytelling.

\section{Discussion And Conclusion}

Amidst the several relevant aspects researched in our study, we may conclude that there are several layers that matter to understand. Firstly, the Alien franchise became a transmedia phenomena, and in doing so it managed to survive decades after so many films and videogames releases. It is important to remember that this happens because Alien franchise is highlighted as a universe 
in itself (with strong connections to the director Ridley Scott) which over time has created a narrative of epic proportions through movies and games, and these have as leitmotiv to unfold various elements. Secondly, no matter which film or game is released everything that is new unfolds from the entry-points and the exit points from the original 1979 Alien movie. What is most interesting is that layer upon layer of meaning both videogames and movies happen to establish what we may call a "Ridley Verse". The director himself calls this way of building a narrative the creation of a giant puzzle. This is why people watch the movies and play the videogames. People want an entry-point and thus to be able to comprehend the fullness, the total immersion in the world of Alien, its scenarios, protagonists and foes.

As a final conclusion, we must also add that nowadays the mainstream viewer or the casual gamer are no more the rule, and this is of the utmost importance. The new audiences are seekers and searchers at the same time, moving around in this new "cyber-geography", demanding for new challenging contents, narratives, games, and interacting freely. We pause the frames, we search the web, we tend to pursue entry-points and easter eggs deliberately left over on the movies and games so that we may have access to the grand narrative scheme, as Sasaki points out. Sometimes, just a visual glitch, a sound effect, a texture, or the light design is enough for our immersion in the story to begin. We, as an audience, have changed since we are simultaneously gamers, readers and viewers, and this situation occured along with the way narrative and storytelling have changed, too. We simply kept up with the current trends in media and cinematic universes.

\section{References}

Alien (Ridley Scott, 1979)

Alien 3 (David Fincher, 1992)

Aliens (James Cameron, 1986)

Aliens: Colonial Marines (SEGA, 2013)

Alien: Covenant (Ridley Scott, 2017)

Alien: Isolation (SEGA, 2014)

Alien Resurrection (Jean-Pierre Jeunet, 1997)

Alien Vs. Predator (Paul Anderson, 2004)

Anderson, C. (2007). The long tail: how endless choice is creating unlimited demand. London, UK: Random House - Business Books.

Bamberg, M. (2012). New image frontiers: defining the future of photography. New York, NY, US / London, UK: Course Technology - CENGAGE Learning.

Bamberg, M. \& Andrews, M. (eds.) (2004). Considering counter narratives - Narrating, resisting, making sense. Amsterdam, Netherlands / Philadelphia, Pensylvania, Us: John Benjamins Publishing Company.

Barthes, R. (1993). La aventura semiológica [1985], (pp. 239-245) $2^{\text {nd }}$ Ed. Barcelona, Spain: Paidós Communicación. 
Barthes, R. (1982). Empire of signs.(Trans. R. Howard). New York, NY, Us: Hill and Wang.

Barthes, R. (n.d.). Crítica e verdade [1980]. San Paulo, SP, Brazil: Editora Perspetiva.

Barthes, R. (1975). The pleasure of the text [1973] (pp. 33-35). New York, NY, US: Hill \& Wang.

Baudrillard, J. (1983). Simulations. Foreign Agents Series, Trans. Paul Foss, Paul Patton \& Philipp Beitchman. New York, NY, US: Semiotext (e).

Bauman, Z. (2000). Liquid modernity. Cambridge, UK: Polity Press.

Bertens, H. (2005). The idea of the postmodern [1995]. New York, NY, US: Routledge.

Blade Runner [DVD] (Ridley Scott, 1982)

Bolter, J. D. \& Gruisin, R. (2002). Remediation: understanding new media (1999). Massachusetts, Cambridge, MA, US: MIT Press.

Bosch, T. (2012, March 2). Sci-fi writer bruce sterling explains the intriguing new concept of design fiction. Future Tense - The Citizen's Guide to The Future, US. Retrieved from www.s late.com/blogs/future_tense/2012/03/02/bruce_sterling_on_design_fictions_html (Access in May 12, 2016)

Bukatman, S. (1993). Terminal identity: the virtual subject in postmodern science fiction. London, UK: Duke University Press.

Cardoso, G. (2013). A sociedade dos ecrãs. Lisbon, Portugal: Ed.Tinta da China.

Castanheira, G. (2012, maio). O Tempo e o Modo, Episode 3 - Lucrécia Martel. Pop, Filmes, Documentários RTP.

Castanheira, G. (2012, maio 31). O Tempo e o Modo, Episode 4 - Gonçalo M. Tavares. Pop Filmes, Documentários RTP.

Deleuze, G. \& Guattari, F. (1999). A Thousand Plateaus - Capitalism and Schizophrenia. (Trans. B. Massumi). London, UK: Athlone Press.

Deleuze, G. \& Guattari, F. (s.d.). O Anti-Édipo - Capitalismo e Esquizofrenia. (Trans. J. M. Varela \& M. M. Carrilho). Lisbon, Portugal: Assírio \& Alvim.

Dick, P. K. (s.d.). Blade runner - perigo eminente ["sonham os andróides com carneiros eléctricos?” (1968)]. $2^{\text {nd }}$ Edition. Mem-Martins, Portugal: Europa-América.

Dick, P. K. (1968). Do androids dream of electric sheep?. London, UK: Grafton.

Douglas Rushkoff - Frontline: the persuaders, PBS (Rachel Dretzin\& Barak Goodman, 2004).

Dowd, T. (2013). Transmedia Storytelling - A Story for All Screens. Retrieved from: http://master ingfilm.com/transmedia-storytelling-a-story-for-all-screens/ (Access in July 12, 2017).

Elias, H. (2016). Brandware - When brands and digital media collide. Australia: Tablo.

Elias, H. (2014). The bridge - a transmedia dialogue between tv, film and gaming. HCI 2014. Heraklion, Crete, Greece, June 22nd-27th.

Elias, H. (2013). Post-Web: the continuous geography of digital media. Odivelas, Portugal: FormalPress. 
Elias, H. (2011). O Gigante fragmentado: públicos e figuras do digital. Domínio 6 - Publicidade e Comunicação do VII Congresso SOPCOM, December 15th-17th. Universidade do Porto, Portugal.

Evans, E. (2011). Transmedia television: audiences, new media and daily life. Comedia series, Morley, D. (ed.). New York, NY, US / London, UK: Routledge.

Flusser, V. (1985). Filosofia da caixa preta. San Paulo, SP, Brazil: Hucitec.

Gibson, W. (2010). Zero history. New York, NY, US: G.P. Putnam's Sons. Apple iBook Store ebook version (Access in January 2015).

Gibson, W. (2003). Pattern recognition. New York, NY, US: G. P. Putnam's Sons.

Giovagnoli, M. (2011). Transmedia storytelling. Imagery, shapes and techniques. (Ed.Max Giovagnoli \& ECTS Press). Apple iBook Store ebook version (Access in August 2014).

Herman, L. \& Vervaeck, B. (2005). Handbook of narrative analysis [2001]. Lincoln and London, UK: University of Nebraska Press.

Hobo, F. \& Elias, H. (2017). Estética Glitch - O "Erro" Icônico. Designa 2016 Erro(r), (6), 173-182. Retrived from: http://designa.ubi.pt/ (Access in July 2017)

Hoepker, K. (2011). No maps for these territories: cities, spaces and archaeologies of the future in william Gibson. Amsterdam, Netherlands / New York, NY, US: Editions Rodopi, BV.

Jenkins, H. (2013). Spreadable media. New York, NY, US: New York University Press.

Jenkins, H. (2006). Convergence culture. New York, NY, US: New York University Press.

Kawamoto, K. (2003). Media and society in the digital age. New York, NY, US: Pearson Education Inc..

Kevin Kelly on How Technology Evolves (Ted Talks, November, 2006)

Locke, C. (2017). Ridley Scott Reveals the Origin of his Androids in the Alien Saga. Wired Magazine, March. Retrieved from URL: www.wired.com/2017/03/ridley-scott-video/ (Access in July 10, 2017).

Lost (Abrams, J.J. et al., ABC, 2004-2010).

Lunenfeld, P. (2011). The secret war between downloading \& uploading. tales of the computer as culture machine. Cambridge, London, UK: MIT Press.

Lyotard, J.-F. (1979). La condition post-moderne. Paris, France: Les Éditions des Minuit.

Machado, A. (2001). Máquina e imaginário. O desafio das poéticas tecnológicas (1993), $3^{\text {rd }}$ edition. San Paulo, SP, Brazil: Ed.USP.

Machado, A. (1997). Pré-cinema e pós-cinemas. Brazil: Editora Papirus.

Meet Walter (n.d). Retrieved from URL: www.meetwalter.com (Access in July 23, 2017)

Meet No Maps For These Territories [2000] - William Gibson (Mark Neale, 2000)

Meet On the Edge of Blade Runner (Andrew Abbott, 2000).

Meet Prometheus (Ridley Scott, 2012) 
Meet Prometheus (n.d.) Retrieved from URL: www.projectprometheus.com (Access in July 22, 2017).

Postman, N. (1994). Meet Tecnopolia - quando a cultura se rende à tecnologia (1992). Lisbon, Portugal: Difusão Cultural.

Rushkoff, D. (2013). Present shock - when everything happen now. Us: Current - Penguin Books. Retrieved from Apple iBooks epub version.

Sasaki, D. M. (2012). Transmedia storytelling and lost: path to success. Master's thesis in digital culture. University of Jyväskylä, Department of Art and Culture Studies, Finlândia. Retrieved from (Access in December $1^{\text {st }}, 2013$ ).

Scolari, C. A. (2009). Transmedia storytelling: implicit consumers, narrative worlds, and branding in contemporary media production. International Journal of Communication, (3), 586-606.

Scott, D. M. (2011). The new rules of marketing \& PR. Hoboken, NJ, US: John Wiley \& Sons.

Star Trek's JJ Abrams and Gabe Newell (Valve Software) [JJ Abrams, February 6, 2013]. Opening Keynote - Storytelling Across Platforms: Who Benefits Most, The Audience or The Player?. DICE Conference, US. Retrieved from www (Access in December 22 $2^{\text {nd }}, 2013$ ).

Taleb, N. N. (2012). Antifragile: things that gain from disorder. iBook ePub version. New York, NY, US: Random House.

Taleb, N. N. (2010). The black swan. New York, NY, US: Incerto, Random House Trade. Amazon Kindle ebook version.

Total Recall (Paul Verhoeven, 1990)

Total Recall 2070: Série 1 (1999) [TV series] (Mario Azzopardi, 1999)

Turkle, S. (2015). Reclaiming conversation - the power of talk in a digital age. New York, NY, US: Penguin Press.

Turkle, S. (2011). Alone together - why expect more from technology and less from each other. New York, NY, US: Basic Books.

Turkle, S. (1997). A Vida no Ecrã. Lisbon, Portugal: Relógio d'Água. 